\title{
Efficacy of Biofeedback Exercise of Deep Neck Flexors on Cervicogenic Headache
}

\author{
MAHA M. AHMED, M.Sc.*; SALWA F. ABD EL-MAGEED, Ph.D.**; KARIMA A. HASSAN, Ph.D.** and \\ EMAD S.B. SAWEERES, F.R.C.S. (Tr \&Orth), M.D.*** \\ The Department of Physical Therapy, El-Tahrir General Hospital, Giza*, \\ The Department of Physical Therapy for Musculoskeletal Disorders, Faculty of Physical Therapy, Cairo University** and \\ The Department of Orthopedic Surgery, El-Sahel Teaching Hospital, Cairo***, Egypt
}

\begin{abstract}
Background: Cervicogenic Headache (CGH) is a common condition causing significant disability. Patients with CGH had less strength and endurance of Deep Neck Flexors (DNF).

Aim of Study: The purpose of this study was to investigate the efficacy of (DNF) strength exercise using Pressure Biofeedback Unit (PBU) for CGH patients.

Material and Methods: Thirty patients (15 females and 15 males) with $\mathrm{CGH}$, their age ranged from twenty to forty years, were randomly allocated into DNF group received DNF strength exercise using PBU in addition to traditional program and traditional treatment group received traditional physical therapy program only. Treatment applied three times per week for 4 weeks, each patient has been assessed for pain, functional disability, and cervical range of motion using Visual Analog Scale (VAS), Neck Disability Index (NDI) and OB Myrin goniometry respectively in addition to headache frequency per week pre and post-treatment.

Results: The results showed that: There was no significant difference in the mean values of the headache pain $(p=0.13)$, neck pain $(p=0.78)$, NDI $(p=0.77)$ and ROM $(p>0.5)$ between DNF group and traditional group post-treatment but there was a significant decrease in the mean values of headache frequency of the DNF group post-treatment compared with that of traditional treatment group $(p=0.003)$.

Conclusion: These results suggest that deep neck flexors exercises using pressure biofeedback unit is effective in the reducing headache frequency in individuals with the cervicogenic headache than traditional exercise only.
\end{abstract}

Key Words: Cervicogenic headache - Chronic neck pain Pressure-biofeedback stabilizer-Deep neck flexors training.

\section{Introduction}

CERVICOGENIC Headache (CGH) is a referred pain from cervical structures innervated by the upper three cervical spinal nerves [1]. This pain is

Correspondence to: Dr. Maha M. Ahmed, The Department of Physical Therapy, El-Tahrir General Hospital, Giza, Egypt unilateral, starting from one side of the posterior head and neck [2] spreading to the frontal-temporal and orbital region [3]

The CGH has a prevalence that varies from $0.4 \%$ to $15 \%$ among all different types of headaches, affecting approximately $2.5 \%$ of the adult with predominance among the female gender $[4,5]$

Management of cervical headache usually focuses on musculoskeletal impairment thought to be causative or contributing to the patient's headaches [6-8] . Treleaven et al., [9] and Jull et al., [10] found that there was a significant inferior DNF muscles performance in subjects with CGH compared to control subjects.

Although studies have been done to assess the effectiveness of manual therapy on headaches [6,11], few have incorporated muscle re-education of the deep neck flexors [12-14] and according to authors knowledge, no previous studies compared the effect of adding strengthening of these muscles in the treatment of cervicogenic headache.

The aim of this study was to investigate the efficacy of (DNF) strength exercise using Pressure Biofeedback Unit (PBU) for CGH patients that may provide a more conclusive program for treatment the patients with $\mathrm{CGH}$.

\section{Material and Methods}

\section{Participants:}

Participants were identified and recruited over 12 month period (from May 2017 to May 2018). Thirty patients diagnosed as chronic mechanical neck pain with cervicogenic headache referred to 
the outpatient Physical Therapy Clinic of at ElTahrir General Hospital, Giza, Egypt.

Subjects who met the following inclusion criteria were asked to participate in the study: (1) Precipitation of head pain by: (Neck movement and/or sustained awkward head positioning, external pressure over the upper cervical or occipital region on the symptomatic side. (2) Unilateral head pain without side shift or bilateral head pain with dominant side which has pain more than the other side. (3) Patients with chronic mechanical neck pain with frequent cervicogenic headache persisting for more than 3 months. (4) Positive flexionrotation test.

Subjects were excluded from the study if they had a history of any of the following condition: Fracture or previous surgery on vertebral column, spinal stenosis, disc prolapsed, TMJ dysfunction or headache with autonomic involvement, dizziness or visual disturbance, congenital condition of cervical spine.

Thirty subjects with age ranged from 20 to 40 years signed an informed consent. The subjects were. Each patient was instructed to choose a paper from a box which contains 30 folded papers, 15 were written by (A) and 15 were written by (B), each patient was assigned to the group that carries the letter which he has chosen to be randomly assigned into the two groups. Fifteen patients ( 9 females and 6 males) were allocated to traditional treatment group and 15 patients ( 10 females and 5 males) were allocated to DNF group.

\section{Assessment procedures:}

Before treatment and after the end of the last session of the 4 weeks of the study period, each subject completed the Visual Analog Scale (VAS) and neck disability index. The 10-cm Visual Analog Scale (VAS) with 0 representing no pain and 10 representing the worst pain imaginable. This method of evaluation has been shown to be both reliable and valid for measuring headache and other chronic pain [15] . In addition to headache frequency assessed after and before sessions. It was defined as the number of headache days per week [13]

All patients were assessed for their functional status pre and post sessions by selecting the answers representing their case from the Arabic version of the NDI that has been validated for the evaluation of functional disabilities due to neck pain (appendix I) [16-18].

All patients were assessed for their cervical range of motion in this in flexion, extension, rota- tion side bending, and rotation combined with flexion (FRT) before and after sessions of the treatment by OB-Myrin Goniometer. It was found that it is valid, and has a moderate to good reliability for measuring cervical spine range of motion [19]

\section{Treatment procedure:}

Each patient in both groups received a three supervised physical therapy sessions per week for 4 weeks of Neck Isometric Exercise (NIE), stretching exercise and Infra-Red (IR) [14,20] . Infrared radiation for 20 minutes and stretching exercises particularly for upper trapezius, scalenes, levator scapulae, and short suboccipital extensors using Post-Isometric Relaxation technique (PIR) that was performed by first passively lengthening the muscle, then having the patient lightly contract (10-20\% of maximum) against resistance for 5 seconds passively before exhaling and relaxing the muscle, the clinician took up the slack within the muscle and repeated the technique 3 times [21].

Isometric exercises were conducted for neck extensors, flexors, side bending and rotators. Patient in the sitting position and therapist stands behind him/her giving resistance by his/her hand for each direction for 10 seconds contraction followed by 5 seconds relaxation, repeated 3 times for each direction 4.5min. as total times for exercise [22] The DNF group received additional exercise for deep neck flexors using PBU.

For deep neck flexors training, the patient lay in hook-lying position with a neutral neck then line up the head and neck so that they were straight. If necessary, a towel can be placed under the head so that a neutral position can be achieved. Therapist placed the pressure sensor underneath the neck and explained to the patient the purpose is not strength but precision. Therapist monitored for substitution of the SCM as pictured as shown in Fig. (1).

Target movement is gently and slowly nod the head as if saying "yes" so that the pressure sensor measures $2 \mathrm{mmHg}$ above baseline $(20 \mathrm{mmHg})$, then $4 \mathrm{mmHg}$, followed by $6 \mathrm{mmHg}, 8 \mathrm{mmHg}$, and 10 $\mathrm{mmHg}$ without rests in between (the pressure sensor should read $30 \mathrm{mmHg}$ at the end of the movement sequence). Patient held each increment for 2 seconds, 10 seconds total after all 5 increments. Highest level achieved was repeated with the correct form until a total of 10 reps with 10 -second holds were achieved in three series with 30 seconds of interval between the series [23]. 


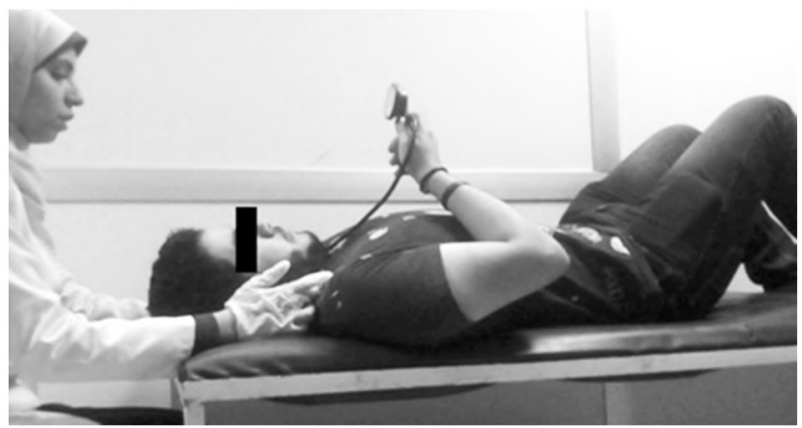

Fig. (1): Deep neck flexor strengthing using pressure biofeedback unit.

\section{Statistical analysis:}

Descriptive statistics and $t$-test were conducted for comparison of the subject characteristics between both groups. Mixed MANOVA was conducted to compare the effect of time (pre versus post) and the effect of treatment (between groups), as well as the interaction between time and treatment on mean values of headache pain intensity and frequency, neck pain, NDI and cervical ROM. Chi squared test was conducted for comparison of sex and affected side distribution between both groups. The level of significance for all statistical tests was set at $p<0.05$. All statistical measures were performed through the Statistical Package for Social Studies (SPSS) Version 22 for windows.

\section{Results}

\section{General characteristics of the subjects:}

The mean age \pm SD of DNF group was 35.41 \pm 6.58 years and that of traditional treatment group was $33.2 \pm 4.73$ years. There was no significance difference between both groups in the mean age $(p=0.38)$ Fig. (2) (Table 1).

\section{Sex distribution:}

The sex distribution of the DNF group revealed that there were 10 females with a reported percentage of $67 \%$ while the number of males was 5 with a reported percentage of $33 \%$. The sex distribution of the traditional treatment group revealed that there were 9 females with a reported percentage of $60 \%$ while the number of males was 6 with a reported percentage of $40 \%$. There was no significant difference in sex distribution between both groups ( $p=0.7)$ Fig. (3) (Table 2).

\section{Affected side distribution:}

Seven (47\%) subjects of the DNF group had the right side affected and $8(53 \%)$ subjects had the left side affected. Eight (53\%) subjects of the traditional treatment group had the right side affected and 7 (47\%) subjects had the left side affected. There was no significant difference in the affected side distribution between both groups ( $p$ $=0.71)$ Fig. $(4)$ (Table 3).

Effect of treatment on headache pain intensity and frequency, neck pain, NDI and cervical ROM:

Mixed MANOVA was conducted to investigate the effect of treatment on headache pain intensity and frequency, neck pain, NDI and cervical ROM. There was no significant interaction effect of treatment and time $(p=0.056)$. There was no significant main effect of treatment $(p=0.86)$. There was a significant main effect time $(p=0.0001)$ (Table 4$)$.

\section{Effect of treatment on headache pain:}

DNF group: The mean difference was 5.33 and the percent of change was $65.96 \%$. There was a significant decrease in headache pain in DNF group post-treatment compared with that pre-treatment ( $p=0.0001)$ Fig. (4). Traditional treatment group: The mean difference was 3.4 and the percent of change was $44.73 \%$. There was a significant decrease in headache pain in traditional treatment group post-treatment compared with that pretreatment $(p=0.0001)$. Multiple pairwise comparisons showed that there was no significant difference in the mean values of headache pain pre-treatment between both groups $(p=0.51)$. Also, there was no significant difference in the mean values of the headache pain between both groups post-treatment $(p=0.13)$ Fig. (5) (Table 5).

\section{Effect of treatment on headache frequency:}

DNF group: The mean difference was 3.17 and the percent of change was $77.7 \%$. There was a significant decrease in headache frequency in DNF group post-treatment compared with that pretreatment ( $p=0.0001)$. Traditional treatment group: The mean difference was 2.6 and the percent of change was $55.31 \%$. There was a significant decrease in headache frequency in traditional treatment group post-treatment compared with that pretreatment ( $p=0.0001)$. Multiple pairwise comparisons showed that there was no significant difference in the mean values of headache frequency pre-treatment between both groups $(p=0.4)$. However, there was a significant decrease in the mean values of headache frequency of the DNF group post-treatment compared with that of traditional treatment group ( $p=0.003)$ Fig. (6) (Table 6).

\section{Effect of treatment on neck pain:}

DNF group: The mean difference was 2.75 and the percent of change was $39.28 \%$. There was a significant decrease in neck pain in DNF group post-treatment compared with that pre-treatment 
$(p=0.003)$. Traditional treatment group: The mean difference was 3.4 and the percent of change was $45.94 \%$. There was a significant decrease in neck pain in traditional treatment group post-treatment compared with that pretreatment $(p=0.001)$. Multiple pairwise comparisons showed that there was no significant difference in the mean values of neck pain pre-treatment between both groups ( $p=$ $0.69)$. Also, there was no significant difference in the mean values of the neck pain between both groups post-treatment ( $p=0.78$ ) Fig. (7) (Table 7).

\section{Effect of treatment on NDI:}

DNF group: The mean difference was $32.17 \%$ and the percent of change was $59.6 \%$. There was a significant decrease in NDI in DNF group posttreatment compared with that pre-treatment $(p=$ $0.0001)$. Traditional treatment group: The mean difference was $29.36 \%$ and the percent of change was $55.83 \%$. There was a significant decrease in NDI in traditional treatment group post-treatment compared with that pre-treatment $(p=0.0001)$. Multiple pairwise comparisons showed that there was no significant difference in the mean values of NDI pre-treatment between both groups ( $p=$ $0.74)$. Also, there was no significant difference in the mean values of the NDI between both groups post-treatment $(p=0.77)$ Fig. (8) (Table 8).

\section{Effect of treatment on flexion ROM:}

DNF group: The mean difference was 6.95 degrees and the percent of change was $18.96 \%$ There was no significant difference in flexion ROM in DNF group between pre and post-treatment ( $p$ $=0.06$ ). Traditional treatment group: The mean difference was 5.02 degrees and the percent of change was $10.57 \%$ there was no significant difference in flexion ROM in traditional treatment group between pre and post-treatment $(p=0.21)$. Multiple pairwise comparisons showed that there was no significant difference in the mean values of flexion ROM pre-treatment between both groups $(p=0.13)$. Also, there was no significant difference in the mean values of the flexion ROM between both groups post-treatment $(p=0.18)$ Fig. (9) (Table 9).

\section{Effect of treatment on extension ROM:}

DNF group: The mean difference was 3.68 degrees and the percent of change was $7.85 \%$ there was no significant difference in extension ROM in DNF group between pre and post-treatment ( $p$ $=0.38$ ). Traditional treatment group: The mean difference was 9.71 degrees and the percent of change was $18.5 \%$ there was a significant decrease in extension ROM in traditional treatment group post-treatment compared with that pre-treatment $(p=0.04)$. Multiple pairwise comparisons showed that there was no significant difference in the mean values of extension ROM pretreatment between both groups $(p=0.34)$. Also, there was no significant difference in the mean values of the extension ROM between both groups post-treatment ( $p=0.92$ ) Fig. (10) (Table 10).

\section{Effect of treatment on right rotation ROM:}

DNF group: The mean difference was -6.37 degrees and the percent of change was $13.65 \%$ There was no significant difference in right rotation ROM in DNF group between pre and post-treatment $(p=0.15)$. Traditional treatment group: The mean difference was 0.5 degrees and the percent of change was $1 \%$ there was no significant difference in right rotation ROM in traditional treatment group between pre and post-treatment $(p=0.91)$. Multiple pairwise comparisons showed that there was no significant difference in the mean values of right rotation ROM pre-treatment between both groups $(p=0.45)$. Also, there was no significant difference in the mean values of the right rotation ROM between both groups post-treatment $(p=0.56)$ Fig. (11) (Table 11).

\section{Effect of treatment on left rotation ROM:}

DNF group: The mean difference was -10.94 degrees and the percent of change was $25.5 \%$ there was a significant increase in left rotation ROM in DNF group post-treatment compared with that pretreatment $(p=0.01)$. Traditional treatment group: The mean difference was -1.25 degrees and the percent of change was $2.61 \%$ there was no significant difference in left rotation ROM in traditional treatment group between pre and post-treatment $(p=0.77)$. Multiple pairwise comparisons showed that there was no significant difference in the mean values of left rotation ROM pre-treatment between both groups ( $p=0.31$ ). Also, there was no significant difference in the mean values of the left rotation ROM between both groups post-treatment ( $p=$ 0.36) Fig. (12) (Table 12).

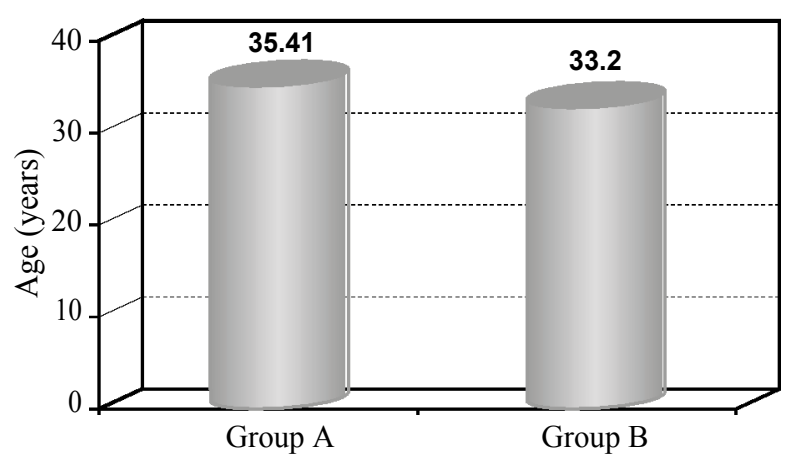

Fig. (2): Mean age of both groups (A and B). 
Group A

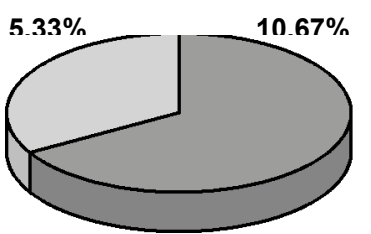

Females
Group B

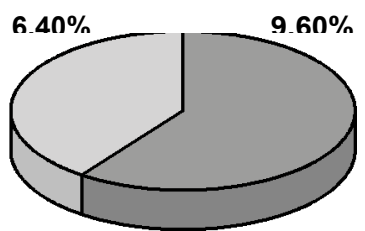

Males

Fig. (3): Sex distribution in group A and B.

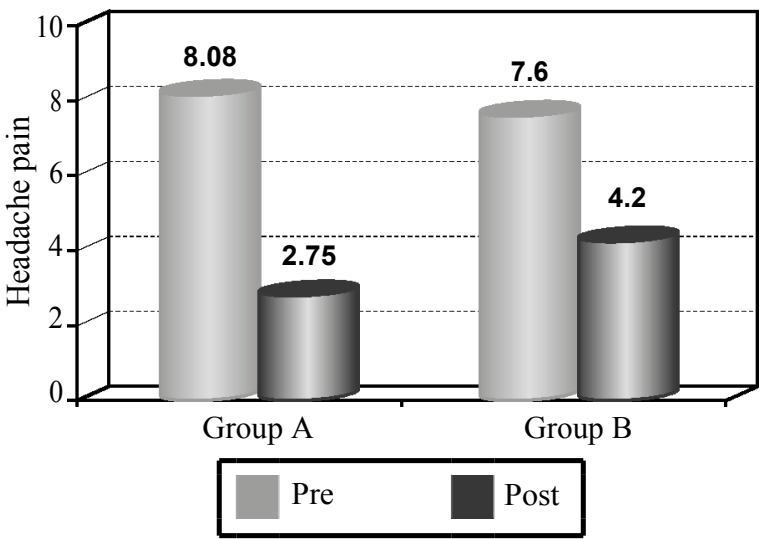

Fig. (5): Mean headache pain pre and post-treatment of both groups (A and B).

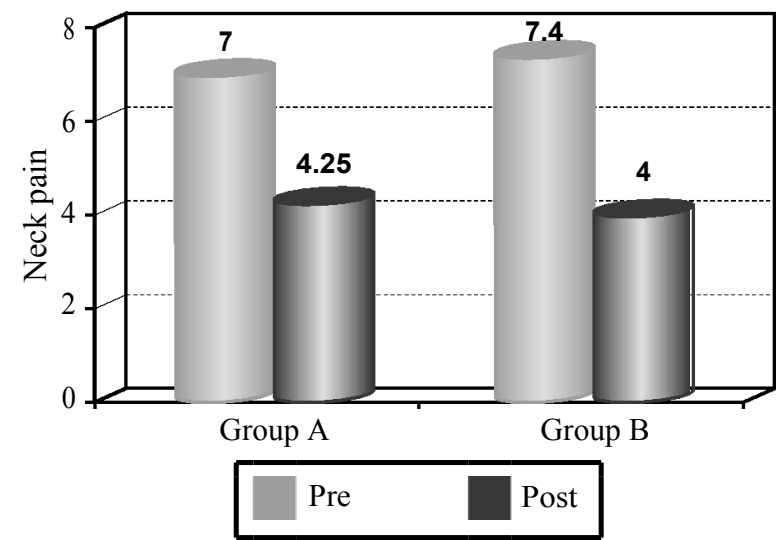

Fig. (7): Mean neck pain pre and post-treatment of both groups (A and $\mathrm{B}$ ).

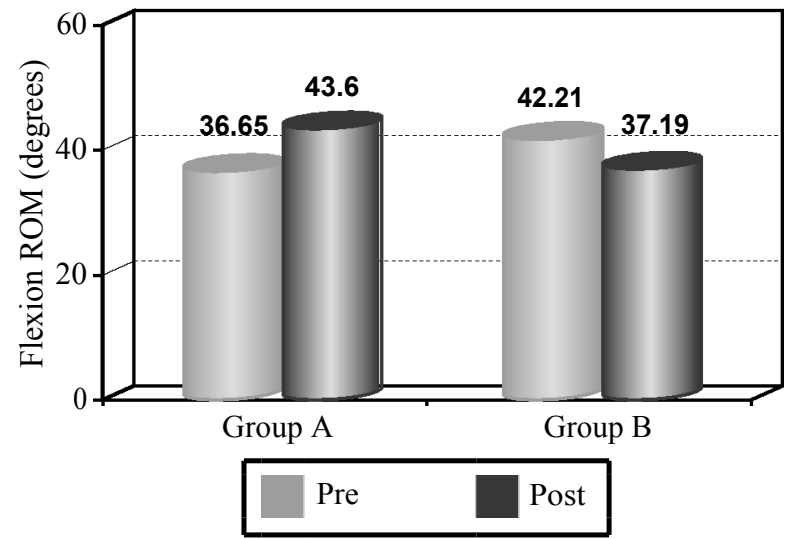

Fig. (9): Mean flexion ROM pre and post-treatment of both groups (A and $\mathrm{B})$.

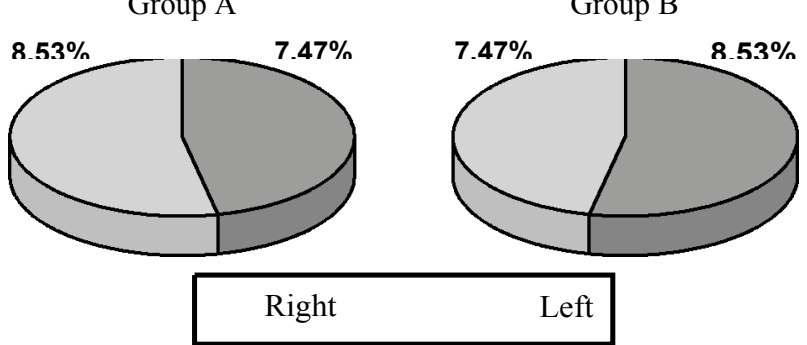

Fig. (4): Sex distribution in group A and B.

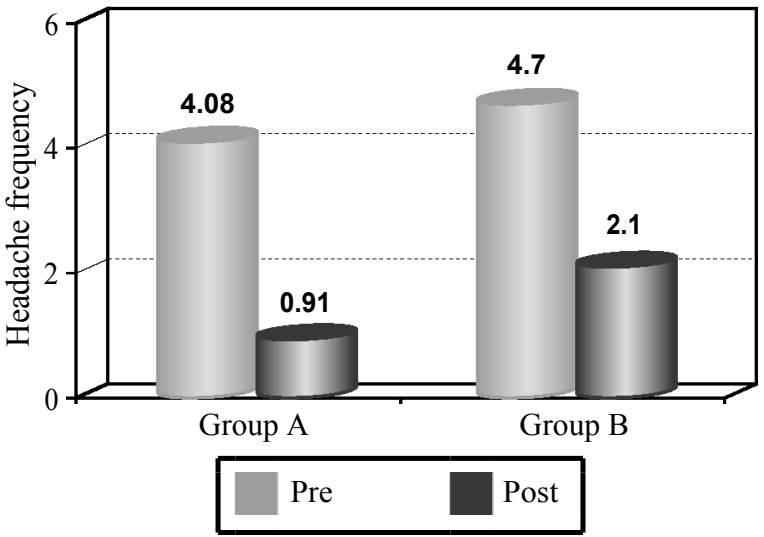

Fig. (6): Mean headache frequency pre and post-treatment of both groups (A and $\mathrm{B}$ ).

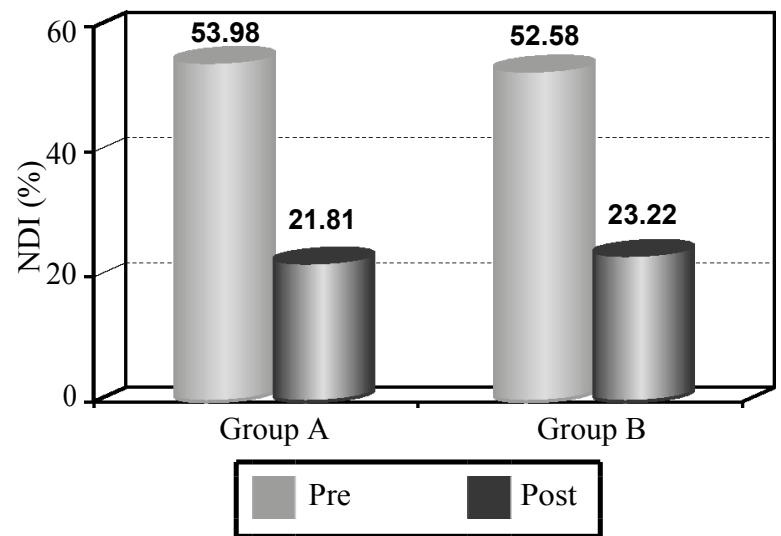

Fig. (8): Mean NDI pre and post-treatment of both groups (A and $\mathrm{B}$ ).

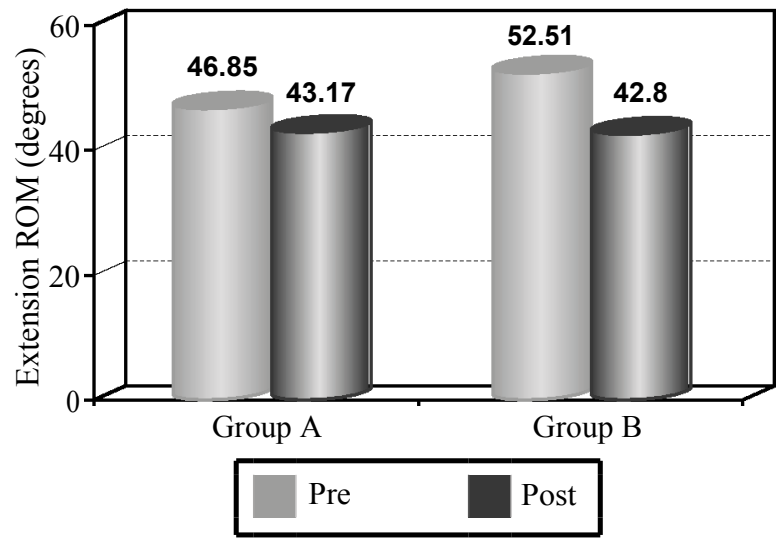

Fig. (10): Mean extension ROM pre and post-treatment of both groups (A and B). 

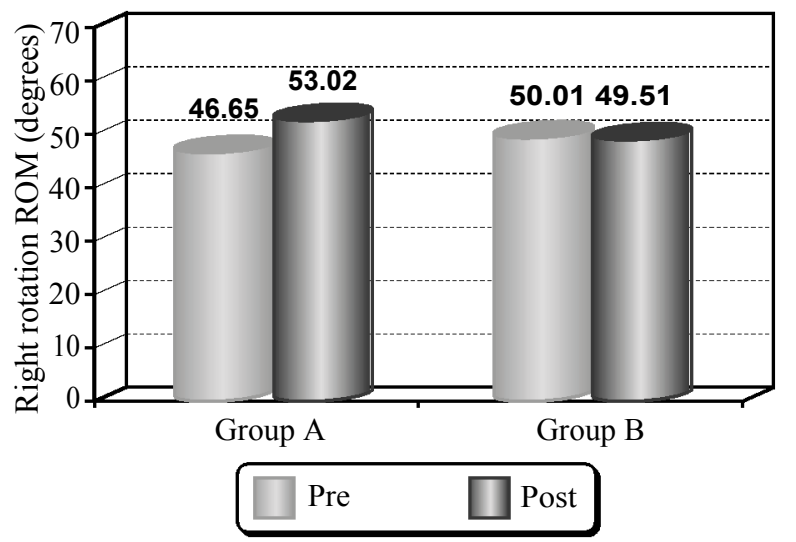

Fig. (11): Mean right rotation ROM pre and post-treatment of both groups (A and B).

Table (1): Descriptive statistics and $t$-test for comparing the mean age of both groups.

\begin{tabular}{|c|c|c|c|c|c|c|}
\hline & $\begin{array}{c}\text { DNF group } \\
\mathrm{X} \pm \mathrm{SD}\end{array}$ & $\begin{array}{c}\text { Traditional } \\
\text { treatment group } \\
\mathrm{X} \pm \mathrm{SD}\end{array}$ & MD & $\begin{array}{c}t- \\
\text { value }\end{array}$ & $\begin{array}{c}p- \\
\text { value }\end{array}$ & Sign. \\
\hline Age (years) & $35.41 \pm 6.58$ & $33.2 \pm 4.73$ & 2.21 & 0.88 & 0.38 & NS \\
\hline $\begin{array}{ll}\mathrm{X} & : \text { Mean. } \\
\mathrm{SD} & : \text { Standa } \\
\mathrm{MD} & : \text { Mean I }\end{array}$ & $\begin{array}{l}\text { rd Deviation. } \\
\text { Difference. }\end{array}$ & $\begin{array}{l}t \text {-value } \\
p \text {-value } \\
\mathrm{NS}\end{array}$ & $: \mathrm{Pr}$ & $\begin{array}{l}\text { abili } \\
\text { Sign }\end{array}$ & $\begin{array}{l}\text { value. } \\
\text { icant. }\end{array}$ & \\
\hline
\end{tabular}

Table (2): The frequency distribution and chi-squared test for comparison of sex distribution between both groups.

\begin{tabular}{lccccc}
\hline & DNF group & $\begin{array}{c}\text { Traditional } \\
\text { treatment group }\end{array}$ & $\begin{array}{c}\chi^{2} \\
\text { value }\end{array}$ & $\begin{array}{c}p- \\
\text { value }\end{array}$ & Sig. \\
\hline $\begin{array}{l}\text { Females } \\
\text { Males }\end{array}$ & $5(37 \%)$ & $9(60 \%)$ & 0.14 & 0.7 & NS \\
\hline
\end{tabular}

$\chi 2$ : Chi squared value $\quad p$-value: Probability value.

NS: Non Significant.

Table (3): The frequency distribution and chi-squared test for comparison of affected side distribution between both groups.

\begin{tabular}{lccccc}
\hline & DNF group & $\begin{array}{c}\text { Traditional } \\
\text { treatment group }\end{array}$ & $\begin{array}{c}\chi^{2} \\
\text { value }\end{array}$ & $\begin{array}{c}p- \\
\text { value }\end{array}$ & Sig. \\
\hline Right & $7(47 \%)$ & $8(53 \%)$ & 0.13 & 0.71 & NS \\
Left & $8(53 \%)$ & $7(47 \%)$ & & & \\
\hline
\end{tabular}

$\chi 2$ : Chi squared value.

NS: Non Significant.

Table (4): Mixed MANOVA for the effect of treatment on headache pain intensity and frequency, neck pain, NDI and cervical ROM.

\begin{tabular}{c} 
Mixed MANOVA \\
Interaction effect (treatment* time) \\
\hline $\mathrm{F}=2.75 \quad p=0.056$ \\
\hline Effect of treatment (group effect) \\
\hline $\mathrm{F}=0.49 \quad p=0.86$ \\
\hline $\mathrm{F}=30.45 \quad$ Effect of time \\
\hline
\end{tabular}

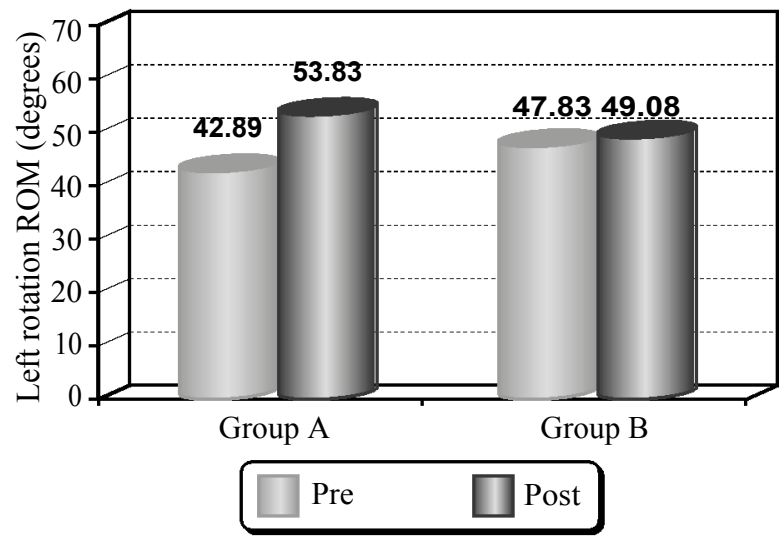

Fig. (12): Mean left rotation ROM pre and post-treatment of both groups (A and B).

Table (5): Mean headache pain pre and post-treatment of bothgroups.

\begin{tabular}{|c|c|c|c|c|c|c|}
\hline Headache pain & $\begin{array}{c}\text { Pre } \\
\mathrm{X} \pm \mathrm{SD}\end{array}$ & $\begin{array}{c}\text { Post } \\
\mathrm{X} \pm \mathrm{SD}\end{array}$ & MD & $\begin{array}{c}\% \text { of } \\
\text { change }\end{array}$ & $\begin{array}{c}p- \\
\text { value }\end{array}$ & Sig. \\
\hline - DNF group & $8.08 \pm 1.67$ & $2.75 \pm 2.41$ & 5.33 & 65.96 & 0.0001 & S \\
\hline $\begin{array}{l}\text { - Traditional } \\
\text { treatment group }\end{array}$ & $7.6 \pm 1.71$ & $4.2 \pm 1.87$ & 3.4 & 44.73 & 0.0001 & S \\
\hline • MD & 0.48 & -1.45 & & & & \\
\hline - $p$-value & 0.51 & 0.13 & & & & \\
\hline - Sig & NS & NS & & & & \\
\hline $\begin{array}{ll}- & : \text { Mean. } \\
\text { SD } & : \text { Standard De } \\
\text { MD } & : \text { Mean Differ }\end{array}$ & $\begin{array}{l}\text { eviation. } \\
\text { rence. }\end{array}$ & $\begin{array}{l}\mathrm{S} \\
\mathrm{NS}\end{array}$ & $\begin{array}{l}\mathrm{Si} \\
\mathrm{Nc}\end{array}$ & $\begin{array}{l}\text { bability } \\
\text { nificant. } \\
\text { n Signifi }\end{array}$ & cant. & \\
\hline
\end{tabular}

Table (6): Mean headache frequency pre and post-treatment of both groups.

\begin{tabular}{|c|c|c|c|c|c|c|}
\hline $\begin{array}{l}\text { Headache } \\
\text { frequency }\end{array}$ & $\begin{array}{c}\text { Pre } \\
\mathrm{X} \pm \mathrm{SD}\end{array}$ & $\begin{array}{c}\text { Post } \\
\mathrm{X} \pm \mathrm{SD}\end{array}$ & MD & $\begin{array}{c}\% \text { of } \\
\text { change }\end{array}$ & $\begin{array}{c}p- \\
\text { value }\end{array}$ & Sig. \\
\hline - DNF group & $4.08 \pm 1.56$ & $0.91 \pm 0.79$ & 3.17 & 77.7 & 0.0001 & S \\
\hline $\begin{array}{l}\text { - Traditional } \\
\text { treatment group }\end{array}$ & $4.7 \pm 1.82$ & $2.1 \pm 0.87$ & 2.6 & 55.31 & 0.0001 & S \\
\hline - MD & -0.62 & -1.19 & & & & \\
\hline - $p$-value & 0.4 & 0.003 & & & & \\
\hline - Sig & NS & $\mathrm{S}$ & & & & \\
\hline Mean. & & & & hal & alue. & \\
\hline SD : Standard D & eviation. & & $: \mathrm{Si}$ & ifica & & \\
\hline
\end{tabular}

Table (7): Mean neck pain pre and post-treatment of both groups.

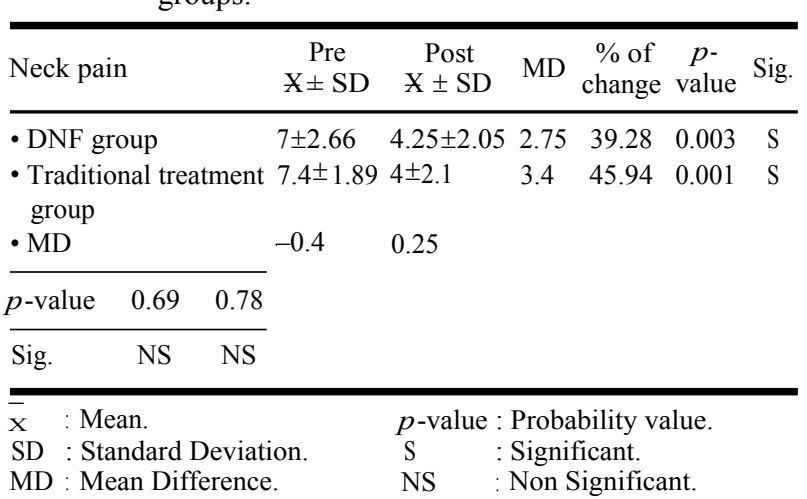


Table (8): Mean NDI pre and post-treatment of both groups

\begin{tabular}{|c|c|c|c|c|c|c|}
\hline NDI (\%) & $\begin{array}{c}\text { Pre } \\
\mathrm{X} \pm \mathrm{SD}\end{array}$ & $\begin{array}{c}\text { Post } \\
\mathrm{X} \pm \mathrm{SD}\end{array}$ & MD & $\begin{array}{c}\% \text { of } \\
\text { change }\end{array}$ & $\begin{array}{c}p- \\
\text { value }\end{array}$ & Sig \\
\hline - DNF group & $53.98 \pm 9.51$ & $21.81 \pm 11.54$ & 32.17 & 59.6 & 0.0001 & S \\
\hline $\begin{array}{l}\text { - Traditional } \\
\text { treatment } \\
\text { group }\end{array}$ & $52.58 \pm 10.02$ & $23.22 \pm 11.34$ & 29.36 & 55.83 & 0.0001 & S \\
\hline - MD & 1.4 & -1.41 & & & & \\
\hline - $p$-value & 0.74 & 0.77 & & & & \\
\hline - Sig & NS & NS & & & & \\
\hline $\begin{array}{ll}\mathrm{x} & : \text { Mean. } \\
\text { SD } & : \text { Standar } \\
\text { MD } & : \text { Mean D }\end{array}$ & $\begin{array}{l}\text { rd Devi } \\
\text { Differen }\end{array}$ & $\begin{array}{l}\mathrm{S} \\
\text { NS }\end{array}$ & $\begin{array}{l}: \mathrm{Si} \\
: \mathrm{Nc}\end{array}$ & iificant & & \\
\hline
\end{tabular}

Table (9): Mean flexion ROM pre and post-treatment of both groups.

\begin{tabular}{|c|c|c|c|c|c|c|}
\hline $\begin{array}{l}\text { Flexion ROM } \\
\text { (degrees) }\end{array}$ & $\begin{array}{c}\text { Pre } \\
\mathrm{X} \pm \mathrm{SD}\end{array}$ & $\begin{array}{c}\text { Post } \\
\mathrm{X} \pm \mathrm{SD}\end{array}$ & MD & $\begin{array}{c}\% \text { of } \\
\text { change }\end{array}$ & $\begin{array}{c}p- \\
\text { value }\end{array}$ & Sig. \\
\hline - DNF group & $36.65 \pm 7.85$ & $43.6 \pm 12.31$ & -6.95 & 18.96 & 0.06 & NS \\
\hline $\begin{array}{l}\text { - Traditional } \\
\text { treatment } \\
\text { group }\end{array}$ & $42.21 \pm 9.1$ & $37.19 \pm 8.64$ & 5.02 & 10.57 & 0.21 & NS \\
\hline - MD & -5.56 & 6.41 & & & & \\
\hline - $p$-value & 0.13 & 0.18 & & & & \\
\hline - Sig & NS & NS & & & & \\
\hline $\begin{array}{ll}\mathrm{X} & : \text { Mean. } \\
\mathrm{SD} & : \text { Standar } \\
\mathrm{MD} & : \text { Mean D }\end{array}$ & $\begin{array}{l}\text { Deviation. } \\
\text { fference. }\end{array}$ & $\begin{array}{l}p \text {-va } \\
\text { S } \\
\mathrm{NS}\end{array}$ & $\begin{array}{l}\text { : Prot } \\
\text { : Sign } \\
\text { : Non }\end{array}$ & $\begin{array}{l}\text { ificant. } \\
\text { Signific }\end{array}$ & ant. & \\
\hline
\end{tabular}

Table (10): Mean extension ROM pre and post-treatment of bothgroups.

\begin{tabular}{|c|c|c|c|c|c|c|}
\hline $\begin{array}{l}\text { Extension } \\
\text { ROM (degrees) }\end{array}$ & $\begin{array}{c}\text { Pre } \\
\mathrm{X} \pm \mathrm{SD}\end{array}$ & $\begin{array}{c}\text { Post } \\
\mathrm{X} \pm \mathrm{SD}\end{array}$ & MD & $\begin{array}{c}\% \text { of } \\
\text { change }\end{array}$ & $\begin{array}{c}p- \\
\text { value }\end{array}$ & Sig. \\
\hline - DNF group & $46.85 \pm 11.83$ & $43.17 \pm 7.04$ & 3.68 & 7.85 & 0.38 & NS \\
\hline $\begin{array}{l}\text { - Traditional } \\
\text { treatment } \\
\text { group }\end{array}$ & $52.51 \pm 15.51$ & $42.8 \pm 11.93$ & 9.71 & 18.5 & 0.04 & S \\
\hline - MD & -5.66 & 0.37 & & & & \\
\hline$\cdot p$-value & 0.34 & 0.92 & & & & \\
\hline - Sig & NS & NS & & & & \\
\hline $\begin{array}{ll}\bar{x} & : \text { Mean. } \\
\text { SD } & : \text { Standard } \\
\text { MD } & : \text { Mean Dif }\end{array}$ & $\begin{array}{l}\text { Deviation. } \\
\text { ference. }\end{array}$ & $\begin{array}{l}p \text {-value : } \\
\mathrm{S} \\
\mathrm{NS}\end{array}$ & $\begin{array}{l}\text { Signi } \\
\text { Non }\end{array}$ & $\begin{array}{l}\text { ficant. } \\
\text { Significa }\end{array}$ & & \\
\hline
\end{tabular}

Table (11): Mean right rotation ROM pre and post-treatment of both groups.

\begin{tabular}{|c|c|c|c|c|c|c|}
\hline $\begin{array}{l}\text { Right rotation } \\
\text { ROM (degrees) }\end{array}$ & $\begin{array}{c}\text { Pre } \\
\mathrm{X} \pm \mathrm{SD}\end{array}$ & $\begin{array}{c}\text { Post } \\
\mathrm{X} \pm \mathrm{SD}\end{array}$ & MD & $\begin{array}{l}\% \text { of } \\
\text { change }\end{array}$ & $\begin{array}{c}p- \\
\text { value }\end{array}$ & Sig. \\
\hline - DNF group & $46.65 \pm 7.73$ & $53.02 \pm 13.84$ & -6.37 & 13.65 & 0.15 & NS \\
\hline $\begin{array}{l}\text { - Traditional } \\
\text { treatment } \\
\text { group }\end{array}$ & $50.01 \pm 12.69$ & $49.51 \pm 14.42$ & 0.5 & 1 & 0.91 & NS \\
\hline - MD & -3.36 & 3.51 & & & & \\
\hline - $p$-value & 0.45 & 0.56 & & & & \\
\hline - Sig & NS & NS & & & & \\
\hline $\begin{array}{ll}\bar{x} & : \text { Mean. } \\
\text { SD } & : \text { Standard } \\
\text { MD } & : \text { Mean Dif }\end{array}$ & $\begin{array}{l}\text { Deviation. } \\
\text { ference. }\end{array}$ & $\begin{array}{ll}\mathrm{S} & : \\
\mathrm{NS} & :\end{array}$ & $\begin{array}{l}\text { Signifi } \\
\text { Non Si }\end{array}$ & $\begin{array}{l}\text { icant. } \\
\text { ignificar }\end{array}$ & & \\
\hline
\end{tabular}

Table (12): Mean left rotation ROM pre and post-treatment of both groups.

\begin{tabular}{|c|c|c|c|c|c|c|}
\hline \multicolumn{2}{|c|}{ ROM (degrees) $X \pm S D$} & $\begin{array}{c}\text { Post } \\
\mathrm{X} \pm \mathrm{SD}\end{array}$ & MD & $\begin{array}{c}\% \text { of } \\
\text { change }\end{array}$ & $\begin{array}{c}p- \\
\text { value }\end{array}$ & Sig. \\
\hline - DNF group & $42.89 \pm 12.61$ & $53.83 \pm 14.17$ & -10.94 & 25.5 & 0.01 & S \\
\hline $\begin{array}{l}\text { Traditional } \\
\text { treatment } \\
\text { group }\end{array}$ & $47.83 \pm 9.19$ & $49.08 \pm 8.23$ & -1.25 & 2.61 & 0.77 & NS \\
\hline - $\mathrm{MD}$ & -4.94 & 4.75 & & & & \\
\hline$\cdot p$-value & 0.31 & 0.36 & & & & \\
\hline - Sig & NS & NS & & & & \\
\hline & & & & & & \\
\hline SD : Standarc & Deviation. & S & : Signific & cant. & & \\
\hline MD : Mean D & ifference. & NS & : Non $\mathrm{Si}$ & gnific & & \\
\hline
\end{tabular}

\section{Discussion}

The main purpose of this study was to investigate the efficacy of deep neck flexor exercise using PBU on pain intensity, headache frequency, functional ability and CROM in cervicogenic headache patients.

\section{Effect of treatment on pain and functional dis- ability:}

There was a significant reduction of headache intensity, neck pain as well as functional disability post treatment in both groups with greater change percent in functional disability $(59.6 \%)$ and headache intensity $(65.96 \%)$ for the DNF group. This may be explained by mechanisms of pain reduction through exercises received by both groups. The increase in endorphins that occurs after training and better neuromuscular control may decrease pain. Muscle contractions activate muscle ergoreceptors (stretch receptors). Afferent from these muscles causes endogenous options to be released and also the beta-endorphins from the pituitary gland. These secretions may cause both peripheral and central pain to be blocked $[24,25]$.

Also neck exercises may allow the musculotendinous proprioceptors to downgrade their stretch reflex responses using operant conditioning techniques and multiple practice sessions. The intrafusal fibers may be reset, discontinuing the cycle of muscle tension, impaired circulation with metabolite accumulation and pain associated with myogenic (myofascial) pain [26]

In addition to previous explanations for pain reduction, heat therapy that applied for both groups is known to have effects on pain and spasm and thus can attribute to pain relief and improved tissue extensibility in both groups. Also Reduction in the pain following static stretching can be explained on the basis of inhibitory effects of Golgi tendon organ and Pacinian corpuscle modification. These 
reflexes allow relaxation in musculotendinous unit tension and decreased pain perception [27]

The neck disability index in the current study showed significant changes in both groups that may be explained by the reduction in pain intensity which can bring about improvement in disability. Herman et al., [28] also proposed that the relationship between pain and neck disability index is quite strong as pain intensity is one of the ten areas addressed in NDI so a relationship between these variables would be expected.

The greater percent of change in pain with DNF group may be based on reduction in cervical impairment as deep cervical flexors, the longuscolli muscle in particular, have a major postural function in supporting cervical lordosis, since in the functional mid-ranges of the cervical spine they lose their endurance capacity in patients with neck pain $[29,30]$

The results of current study disagreed with Iqbal et al., [31] who investigated whether deep cervical flexor exercise with PBU has any significant advantage over traditional treatment for neck pain and disability by school teachers experienced with chronic neck pain and mild disability that was different from subjects participated in the current study who experienced CGH with different levels of disability in addition to their older age ranged from 30 to 40 years old. Findings of Iqbal et al., [31] showed significant improvement of DNF exercise with PBU through four sessions per week for four weeks over physical therapeutic exercise for pain and disability using numeric pain rating scale and NDI.

Findings of present study contradicted with the work of Nezamuddin et al., [32] who found that addition of PBU to traditional program appeared to increase deep cervical flexor muscle performance and reduce neck pain compared to the exercise program alone for people with reduced muscle performance. Nezamuddin et al., [32] followed the protocol described by Jull et al., [13] for craniocervical flexion exercise similar to current study but compared to different traditional program in which scapular muscles were added to neck muscles stretch that may help in postural correction reducing neck pain with respect to the longer duration of physical therapy intervention by Nezamuddin et al., [32], 6 weeks (5 days per week), than current study, four weeks (3 days each week).

In support with current study Chung and Jeong [33] found no significant difference in NDI between Neck Isometric Exercise (NIE) and (CCF) exercise although the study applied for chronic neck pain while current study applied for CGH associated with chronic neck pain with respect to previous prescribed methodological differences.

Parisa et al., [34] agreed with the findings of the present study regarding to neck pain and NDI demonstrating significant decrease in neck pain and NDI in both, Stabilization Exercise group (SE) and Proprioceptive Neuromuscular Facilitation Exercises group (PNFE), without significant difference. Parisa et al., [34] agreed with current results but by intensive program includingsix neck stabilization exercises in addition to Cranio-Cervical Flexion (CCF) exercise using pressure biofeedback unit and within a longer duration 6 times a week over 8 weeks which mean current study showed the same results by receiving DNF exercise guided by PBU added to traditional program with in only 3 times a week over 4 weeks. Parisa et al., [34] assessed the cross-sectional area of deep cervical flexor muscles that not assessed in current study demonstrating that cross-sectional area of deep cervical flexor muscles increased in both treatment groups with significant increase in SE group that may explain why the percent of change in current study improved in experimental group compared to control group.

In support with current study regarding headache and neck pain Yadav and Goyal [35] found that VAS score showed significant improvement in both biofeedback exercisefor deep neck flexors and muscle energy technique group after 2 weeks of treatment as compared to traditional group although the same study disagreed with NDI results of current study as Yadav and Goyal [35] found that the between group difference of NDI was significantly improved in biofeedback exercise of deep neck flexors group after 2 weeks of treatment as compared with muscle energy technique group and traditional group. The traditional treatment received in the study of Yadav and Goyal [35] included MHP (Moist Heat Pack), static stretching exercises, cervical spine non thrust mobilization, cervical spine active ROM exercises and postural exercise while in current study it has consisted of PIR technique and isometric neck exercise combined with IR application. The difference of duration related to intervention should be considered as it was shorter in the study of Yadav and Goyal [35], 2 weeks, than that of the current study, 4 weeks.

In support to current study, Gallego et al., [36] compared the effect of the CCF exercise with cervical proprioception exercise on the neuromus- 
cular control in patients with chronic neck pain. Those patients who received cervical proprioception exercise demonstrated favorable improvements in activation and endurance of deep cervical flexors, neck pain, and disability and no significant difference was reported between the two exercise groups, although the different duration of treatment programs. The work of Gallego et al., [36] lasted for 2 months while in the current study duration of treatment was only 4 weeks.

Ask et al., [37] supported current study regarding NDI and pain although the methodological differences between his work and current study, they found no significant difference between the CCF exercise and a 'dynamic isometric' neck strengthening exercise based on work by Dr. JariYlinen that has been shown to be effective in reducing chronic neck pain [38] as well as cervicogenic headaches [39]. Ask et al., [37] recruited only women whiplash patients aged 18-67 years to perform one or two sessions per week over a period of 6 weeks with a minimum of six and a maximum of 10 sessions to be assessed after 6 weeks and followed by 1 year.

Falla et al., [40] agreed with current results as who compared the effect of endurance-strength exercise regime for the cervical flexor musculature with CCF using PBU on 58 female patients with chronic neck pain suggesting that there was no difference between groups for change in pain or NDI score. Although the similar results, participants and duration of treatment, the results of Falla et al., [40] were different from the current study. Falla et al., [40] recruited only female patients with chronic neck pain with NDI scored less than 15 to be treated once per week twice a day over 7 weeks while current study applied on CGH patients with chronic neck pain without restriction to sex or NDI score to be treated three times per week over 4 weeks. Both studies have no follow-up assessment.

According to our knowledge few studies evaluated intensity of headache pain as a separate variable using pain scales [35], most of the studies assessed headache pain as apart of functional disability scales like NDI $[\mathbf{3 1}, \mathbf{3 3 , 3 4 ]}$ or as a part of headaches scales like headache disability index $[\mathbf{1 4 , 4 1 ]}$, due to this reason our results regarding headache pain cannot be compared to various studies.

\section{Effect of treatment on the cervical range of motion: \\ Regarding to flexion ROM there was no signif- icant difference in between pre and post-treatment}

for both groups that may be due to stretching exercise performedfor only one side as PIR technique applied for the affected side with the headache while chronic neck patient experienced short muscles in both sides.

Regarding to extension ROM there was a significant decrease between pre and post-treatment for conventional treatment group that may be explained by the theory suggested that damage of soft tissue and increase of tension in neck limits stationary contraction of the deep cervical muscle, posing difficulty in sustaining upright neck posture $[42,43]$. With this process, cervical pain and cervicogenic headache occur and as pain occurs or aggravates from the motion of returning to normal posture [44], most of the cervicogenic headache patients take forward neck posture [29] increasing cervical lordosis. By cranio-cervical flexor exercise, the endurance of the DNF improves and the degree of cervical lordosis decrease because cervical posture is related more closely to muscular endurance than to muscular strength of the DNFs which means that $\mathrm{CCF}$ is less effective at reducing superficial cervical flexor muscle fatigue as well as increasing cervical flexion strength when compared with endurance-strength exercise in patients with CNP affecting ROM [42]

Findings of present study were disagreed by the work of Kang [45] who examined the effectiveness of deep cervical flexor exercise with a pressure biofeedback unit on maintaining forward head posture, muscular endurance, and cervical mobility in student college suggesting significant increase in cervical ROM between post-training, after six weeks of training, and the four-week detraining period, compared to the control group. These contradicted results may be due to missing follow-up in current study or different criteria of participated subjects. The study of Kang [45] included chronic neck pain subjects experienced a headache and FHP with younger age while current study included chronic neck pain subjects experienced only headache with older age ranged 20:40 years.

Other differences were the period of intervention and time of assessment. Although both works were performed three times a week, the work of Kang [45] extend to 6weeks and the measurements were repeated three times: Before training, after six weeks of training, and following four weeks of detraining while in current study the program was only for 4 weeks and the measurements were repeated only before and after four weeks of training, another methodological difference was the traditional program in the work of Kang [45], it was 
consisted of traditional deep cervical flexor exercise $15-20 \mathrm{~m}$ performed once a day and stretching $10 \mathrm{~m}$ while in the current study it was consisted of heat application, isometric neck exercise and stretching by post PIR technique repeated three times per week.

Contradicting to current study Abd El-Aziem and Draz [22] found that deep neck flexor exercises have significant increase for flexion, extension and transverse ROM after one-month of treatment and maintained at three-month follow-up in chronic neck pain subjects. Abd El-Aziem and Draz [22] used universal goniometry to assess ROM while in current study OB Myrin goniometry was used for ROM measurements and this methodological differences may potentially account for our contradicting results. These contradicting results of $\mathrm{Abd}$ El-Aziem and Draz [22] work also may be due to absence of pressure biofeedback unit in deep neck flexor exercises or performing stretching for both sides as in current study MET applied for the affected side experienced by neck pain and headache, another methodological difference is the time of physical therapy intervention that repeated by Abd El-Aziem and Draz [22] four weeks (five days each week) in addition to adding home program twice daily while in current study sessions performed only four weeks (3 days each week).

In support to current results regarding to flexion ROM Yadav and Goyal [35] found that the deep neck flexor exercise using pressure biofeedback unit showed no significant improvement compared to traditional and MET groups after 2 weeks treatment protocol although Yadav and Goyal [35] used universal standard goniometer for ROM assessment while current study used OB Myrin goniometry. The findings of the current study regarding extension ROM disagreed with work by Yadav and Goyal [35] indicating that the between group difference of extension ROM was significantly improved in deep neck flexor group compared to traditional and MET groups after 2 weeks of treatment. These contradicting results may be due to different traditional treatment received in the study of Yadav and Goyal [35] as prescribed before as well as shorter duration of intervention it was 2 weeks in the study of Yadav and Goyal [35] while in current study it was 4 weeks. Also the differences may be due to different participant populations as they were with only chronic neck pain with exclusion for headache in the study of Yadav and Goyal [35] but in current study cervicogenic headache subjects were included.
In support Chung and Jeong [33] compared the effects of Neck Isometric Exercise (NIE) and Cranio-Cervical Flexion exercise (CCF) on Active Cervical Range of Motion (ACROM) in all three planes in patients with non-specific, Chronic Neck Pain (CNP) showing significant increases on AC$\mathrm{ROM}$ in all three planes after each intervention with no significant differences between groups. Chung and Jeong [33] used a cervical range of motion instrument for ROM assessment while in the current study ROM assessed by OB goniometry. These different instruments for measuring showed the same results as well as the different duration of physical therapy intervention. The program in the study of Chung and Jeong [33] was performed 3 times a week, for 8 weeks while in current study 4 weeks ( 3 days each week) which add additional advantage to current studyachieving the same results in shorter time.

\section{Effect of treatment on headache frequency:}

According to our knowledge few studies assessed the efficacy of CCF exercise on headache frequency, but most of them used headache disability index $[\mathbf{1 4 , 2 0 ]}$ contradicted to current study which defined headache frequency as the number of headache days per week [13]. Although Islam et al., [14] and Nambi et al., [22] used headache disability index, Islam et al., [14] agreed with current results while Nambi et al., [20] disagreed.

Nambi et al., [20] compared DNFs exercise using PBU to a different intervention; $\mathrm{C} 1-\mathrm{C} 2$ selfSustained Natural Apophyseal Glide (SNAG); from that was used in current study; MET, IR, and isometric neck exercise; that maybe explain the contradicting results which showed that $\mathrm{C} 1-\mathrm{C} 2$ self SNAG was more effective than deep cervical flexor's exercise using pressure biofeedback in decreasing pain intensity and headache disability over a period of 4 weeks for the management of CGH.

Finding of present study supported by the work of Islam et al., [14] who evaluated the effectiveness of PBU as an add-on therapy with traditional exercise on deep cervical strength and headache disability index in patient with cervicogenic headache suggesting that pressure biofeedback group has shown significant improvement in headache disability score as compared to control group at the end of trial.

Islam et al., [14] assessed headache frequency through headache disability index while in current study it was defined as the number of headache days per week [13] but this difference didn't affect 
the result. Islam et al., [14] agreed with the results of current study although the traditional program was different. Islam et al., [14] used moist heat, passive stretching and manual traction as traditional treatment while in current study traditional program consisted of IR application, PIR technique for stretching and isometric neck exercise. The study of Islam et al., [14] confirmed the finding of current results regarding to headache frequency but with the shorter duration for intervention ( 3 weeks) than that of the current study (4 weeks).

Also Jull et al., [13] grouped 200 cervicogenic headache patients into control group, joint movement group, cranio-cervical flexion group, and compound intervention group reporting that subjects with cranio-cervical flexion exercise and compound intervention showed significant difference in cervical curvature sustainment and headache frequency than control and joint movement group, which was identical to the outcome with the most prominent reduction in cranio-cervical flexion exercise group in this study. Although the agreed results with Jull et al., [13], the current study added advantage to get the same results in shorter duration of treatment. Jull et al., applied the intervention for 6 weeks while the current study conducted only for 4 weeks.

In support to current results Beeton and Jull [12] and Shannon [46] demonstrated effectiveness of deep cervical flexor's exercise (using pressure biofeedback unit) in reducing the headache frequency that may be explained by the role of DNF exercise in improving the interaction between the deep and superficial flexor muscles to be closer to the normal situation [46] with respect to the role of PBU. Pressure biofeedback guided DNF exercise may provide an external feedback to the patient regarding his performance of task [46] as well as information from proprioception that increase the average of firing rate, motor unit recruitment and increase synchronization of the active motor unit improving muscle strength and performance by motor learning [20] correcting the faulty posture aggravates headache and neck pain.

\section{Conclusion:}

Adding of strengthening of deep neck flexors exercise with a pressure biofeedback unit to traditional protocol added more beneficial outcomes in relation to headache frequency after 4 weeks.

\section{References}

1- NAROUZE S.: Essentials of Pain Medicine, ${ }^{3 r d}$ edition, 2011.
2- ANTONACI F. and SJAASTAD O.: Cervicogenic headache: A real headache. Curr. Neurol. Neurosci. Rep., 11 (2): 149-55, 2011.

3- CEPHALALGIA; TheInternational Classification of Headache Disorders, ${ }^{2 n d}$ ed. 24 (1): 9-160, 2004.

4- SILVA JÚNIOR A.A., MORAES D.N., REZENDE F.B., PEREIRA G.L., MORATO E.G., CUNNINGHAN M.C.Q.S., et al.: Frequency of types of headache in the tertiary care center of the Hospital das Clínicas of the Federal University of Minas Gerais. Migrâneas Cefaleias, 11 (2): 67-72, 2008.

5- RACHID R.M. and PINHEIRO L.T.M.: Osteopathic manipulative therapy on cervicogenic headache RBPS, 22 (2): 128-34, 2009.

6- NILS SON N., CHRISTENSEN H.W. and HARTVIGSEN $\mathrm{J}$.: The effect of spinal manipulation in the treatment of cervicogenic headache. J. Manip. Physiol. Ther., 20 (5): 326-30, 1997

7- JULL G.: The use of high and low velocity cervical manipulative therapy procedures by Australian manipulative physiotherapists. Aust. J. Physiother., 48 (3): 18993, 2002.

8- KELMAN L.: Migraine changes with age: IMPACT on migraine classification. Headache, 46: 1161-71, 2006.

9- TRELEAVEN J., JULL G. and ATKINSON L.: Cervical musculoskeletal dysfunction in post-concussional headache. Cephalalgia, 14 (4): 273-9, 1994.

10-JULL G., AMIRI M., BULLOCK-SAXTON J., DARNELL R. and LANDER C.: Cervical musculoskeletal impairment infrequent intermittent headache. Part 1: Subjects with single headaches. Cephalalgia, 27 (7): 793-802, 2007.

11- WHORTON R. and KEGERREIS S.: The use of manual therapy and exercise in the treatment of chronic cervicogenic headaches: A series of case studies. J. Man. Manipulative Ther., 8 (4): 193-203, 2000.

12- BEETON K. and JULL G.: Effectiveness of manipulative physiotherapy in the management of cervicogenic headache: A single case study. Physiotherapy, 80: 417-23, 1994.

13- JULL G., TROTT P., POTTER H., ZITO G., NIERE K., SHIRLEY D., EMBERSON J., MARSCHNER I. and RICHARDSON C.: A Randomized Controlled Trial of exercise and Manipulative Therapy for Cervicogenic Headache: Spine, 27 (17): 1835-43, 2002.

14- ISLAM R., QUDDUS N., MIRAJ M. and ANWER S.H. Efficacy of deep cervical flexor strength training versus conventional treatment in cercicogenic headache. Int. J. Cur. Res. Rev., 05 (08): P 84-90, 2013.

15- LUNDQVIST C., BENTH J.S., GRANDE R.B., AASETH K. and RUSSELL M.B.: A vertical VAS is a valid instrument for monitoring headache pain intensity. Cephalalgia, 29 (10): 1034-41, 2009.

16- VERNON H.: The Neck Disability Index: State-of-theArt. J. Manipulative Physiol. Ther., 31 (7): 491-502, 2008.

17- SHAHEEN A.A., OMAR M.T. and VERNON H.: Crosscultural Adaptation, Reliability, and Validity of the Arabic Version of Neck Disability Index in Patients With Neck Pain. Spine, 38 (10): 609-15, 2013. 
18- ALMEIDA R.S., GOMES V., GAULLIER C.M., DAMES K.K. and NOGUEIRA L.A.C.: Effects of manual therapy on cervicogenic headaches: A therapeutic approach Acta. Fisiatr., 21 (2): 53-7, 2014.

19- MALMSTROM E., KARLBERG M., MELANDER A., et al.: Zebris versus Myrin: A comparative study between a three-dimensional ultrasound movement analysis and an inclinometer/compass method: Intra-device reliability, concurrent validity, inter-tester comparison, intratester reliability, and intra-individual variability. Spine, 28 (21): 433-40, 2003.

20- NAMBI G.S., PANCHOLI D.P., TRIVEDI P.S., MOMIN S.M. and PATEL S.: Compararive effect between C1-C2 self-sustained natural apophyseal glide (SNAG) and deep cervical flexors strength training in the managemaent of cervicogenic headache. International Journal of Pharmacological Screening Methods, 4 (2): 69-73, 2014.

21- PAGE P.: Clinical suggestion cervicogenic headache. An evidence-led approach to clinical management. IJSPT, 6 (3): 254-66, 2011.

22- ABDEL-AZIEM A.A. and DRAZ A.H.: Efficacy of deep neck flexor exercise for neck pain: A randomized controlled study. Turk. J. Phys. Med. Rehab., 62: 107-15, 2015.

23- JULL G.A., FALLA D., VICENZINO B. and HODGES P.W.: The effect of therapeutic exercise on activation of the deep cervical flexor muscles in people with chronic neck pain. Man. Ther., 14 (6): 696-701, 2009.

24- FLORAS T.P.: Endorphins and Exercise-Physiological mechanism and clinical implication. J. Med. Sci. Sports Exerc., 22: 417-28, 1990.

25- SMITH H.S.: Peripherally-acting, 2008.

26- Pioids. Pain physician, 11 (2): 121-32.

27- HUTTON R.S. and ATWATER S.W.: Acute and chronic adaptation of muscle proprioceptors in response to increased use. Sports Med., 14: 406-21, 1992.

28- FRYER G. and RUSZKOWSKI W.: The influence of contraction duration in muscle energy technique applied to the atlanto-axial joint. Journal of Osteopathic Medicine, 7 (2): 79-84, 2004.

29- HERMANN K.M. and REESE C.S.: Relationship among selected measures of impairment functional limitation and disability in patients with cervical spine disorders, Phy. Th., 81 (3): 903-14, 2001.

30- WATSON D.H. and TROTT P.H.: Cervical headache: An investigation of natural head posture and upper cervical flexor muscle performance. Cephalalgia, 13: 272-84, 1993.

31- FALLA D., JULL G., RUSSEL T., et al.: Effect of neck exercise on sitting posture in patients with chronic neck pain. Phys. Ther., 87: 408-17, 2007.

32- IQBAL Z.A., RAJAN R., KHAN S.A. and ALGHADIR A.H.: Effect of deep cervical flexor muscles training using pressure biofeedback on pain and disability of school teachers with neck pain. J. Phys. Ther. Sci., 25 (6): 65761, 2013.

33- NEZAMUDDIN M., ANWER S.H., KHAN S.A. and EQUEBAL: A Efficacy of pressure-biofeedback guided deep cervical flexor training on neck pain and muscle performance in visual display operators. Journal of Mus- culoskeletal Research, 16 (3). Headache: Spine, 27 (17): 1835-43, 2013.

34- CHUNG S. and JEONG Y.G.: Effects of the craniocervical flexion and isometric neck exercise compared in patients with chronic neck pain: A randomized controlled trial. Physiotherapy Theory and Practice, 24: 1-10, 2017.

35- PARISA G.H., AHMADREZA A., MOHAMMAD H., ASGHAR A., LEILA R. and FATEME G.: Investigating the effect of stabilization exercise and proprioceptive neuromuscular facilitation exercises on cross-sectional area of deep cervical flexor muscles in patients with chronic non-specific neck pain. International Journal of Medical Research \& Health Sciences, 5 (11): 502-8, 2016.

36- YADAV H. and GOYAL M.: Efficacy of muscle energy technique and deep neck flexors training in mechanical neck pain. A randomized clinical trial. Int. J. Ther. Rehabil. Res., 4 (1): 52-66, 2015.

37- GALLEGOIZQUIERDO T. , PECOS-MARTIN D., LLUCHGIRBÉS E., et al.: Comparison of cranio-cervical flexion training versus cervical proprioception training in patients with chronic neck pain: Arandomized controlled clinical trial. J. Rehabil. Med., 48 (1): 48-55, 2016.

38- ASK T., STRAND L.I. and SKOUEN J.S.: The effect of two exercise regimes; motor control versus endurance/ strength training for patients with whiplash-associated disorders: A randomized controlled pilot study. Clin. Rehabil., 23 (9): 812-23, 2009.

39- YLINEN J., TAKALA E.P., NYKÄNEN M., HÄKKINEN A., MÄLKIÄ E., POHJOLAINEN T. , KARPPI S.L., KAUTIAINEN H. and AIRAKSINEN O.: Active Neck Muscle Training in Treatment of Chronic Neck Pain in Women-A Randomized Controlled Tria. J.A.M.A., 289 (19): 2509-16, 2003.

40- FALLA D., JULL G., HODGES P. and VICENZINO B.: An endurance-strength training regime is effective in reducing myoelectric manifestationsof cervical flexor muscle fatigue in females with chronic neck pain. Clin. Neurophysiol., 117: 828-37, 2006.

41- YLINEN J., NIKANDER R., NYKÄNEN M., KAUTIAINEN H. and HÄKKINEN A.: Effect of neck exercise on cervicogenic headache: A randomized controlled trial. J. Rehabil. Med., 42 (4): 344-9, 2010.

42- JULL G., KRISTJANSSON E. and DALL'ALBA P. Impairment in the cervical flexors: A comparison of whiplash and insidious onset neck pain patients. Man. Ther., 9: 89-94, 2004.

43- BAE W., LEE K. and KIM Y.: Comparison between McKenzie stretch exercise and scapula stability exercise on neck muscle activation in the forward head posture. Journal of The Korean Society of Integrative Medicine, 4: 13-20, 2016.

44- GONG W., KIM C. and LEE Y.: Correlations between cervical lordosis, forward head posture, cervical ROM and the strength and endurance of the deep neck flexor muscles in college students. J. Phys. Ther. Sci., 24: 2757, 2012.

45- O'LEARY S., JULL G., et al.: Specificity in retraining craniocervical flexor muscle performance. J. Orthop. Sports Phys. Ther., 37 (1): 3-9, 2007. 
46- KANG D.Y.: Deep cervical flexor training with a pressure biofeedback unit is an effective method formaintaining neck mobility and muscular endurance in college students with forward head posture. J. Phys. Ther. Sci., 27: 3207$10,2015$.

47- SHANNON M. PETERSON: Articular and muscular impairments in cervicogenic headache, Acase report.
Journal of Orthopedic and Sports Physical Therapy, 33 (1): 21-30, 2003.

48- WALY S.M., OZDOMAR O., KLINE J., ASFOUR S.S and KHALIL T.M.: The role of feedback information in isometric muscle training. Proc. 39 th Annual Conf Engineering in Medicine and Biology, Baltimore, Marylar, p. $35,1986$.

\section{APPENDIX Neck Disability Index f+t+}

Name

Date

This questionnaire has been designed to give your therapist information as to how your neck pain has affected you in your everyday life activities. Please answer each section; marking only ONE box which best describes your status today.

\begin{tabular}{|c|c|}
\hline $\begin{array}{l}\text { Section 1: Pain intensity: } \\
\text { I have no pain at the moment. } \\
\text { The pain is very mild at the moment. } \\
\text { The pain is moderate at the moment. } \\
\text { The pain is fairly severe at the moment. } \\
\text { The pain is very severe at the moment. } \\
\text { The pain is the worse imaginable at the moment. }\end{array}$ & $\begin{array}{l}\text { Section 2: Personal care (washing, dressing, etc.): } \\
\text { I can look after myself normally without causing extra pain. } \\
\text { I can look after myself normally but it causes me extra pain. } \\
\text { It is painful to look after myself and I am slow and careful. } \\
\text { I need help every day in most aspects of self-care. } \\
\text { I do not get dressed, wash with difficulty and stay in bed. }\end{array}$ \\
\hline $\begin{array}{l}\text { Section 3: Lifting: } \\
\text { I can lift heavy weights without extra pain. } \\
\text { I can lift heavy weights but it gives extra pain. } \\
\text { Pain prevents me from lifting heavy weights off } \\
\text { the floor, but I can manage light to medium weights } \\
\text { if they are conveniently positioned. } \\
\text { I can lift only very lightweights. } \\
\text { I cannot lift or carry anything at all. }\end{array}$ & $\begin{array}{l}\text { Section 4: Reading: } \\
\text { I can read as much as I want to with no pain in my neck. } \\
\text { I can red as much as I want to with slight pain in my neck. } \\
\text { I can read as much as I want with moderate pain in my neck. } \\
\text { I can't read as much as I want because of moderate pain in my } \\
\text { neck. } \\
\text { I can hardly read at all because of severe pain in my neck. } \\
\text { I cannot read at all. }\end{array}$ \\
\hline $\begin{array}{l}\text { Section 5: Headache: } \\
\text { I have no headache at all. } \\
\text { I have slight headaches, which come infrequently. } \\
\text { I have moderate headaches, which come infrequently. } \\
\text { I have moderate headaches, which come frequently. } \\
\text { I have severe headaches, which come frequently. } \\
\text { I have headaches almost all the time. }\end{array}$ & $\begin{array}{l}\text { Section 6: Concentration: } \\
\text { I can concentrate fully when I want to with no difficulty. } \\
\text { I can concentrate fully when I want to with slight difficulty. } \\
\text { I have a fair degree of difficulty in concentrating when I want to. } \\
\text { I have a lot of difficulty in concentrating when I want to. } \\
\text { I have a great deal of difficulty in concentration when I want to. } \\
\text { I cannot concentrate at all. }\end{array}$ \\
\hline $\begin{array}{l}\text { Section 7: Work: } \\
\text { I can do as much as I want. } \\
\text { I can only do my usual work but no more. } \\
\text { I can do most of usual work, but no more. } \\
\text { I cannot do my usual work. } \\
\text { I can hardly do any work at all. } \\
\text { I can't do any work at all. }\end{array}$ & $\begin{array}{l}\text { Section 8: Driving: } \\
\text { I can drive my car without any neck pain. } \\
\text { I can drive my car as long as I want with slight pain in my neck. } \\
\text { I can drive my car as long as I want with moderate pain in my } \\
\text { neck. } \\
\text { I can't drive my car as long as I want because of moderate pain } \\
\text { in my neck. } \\
\text { I can hardly drive at all because of severe pain in my neck. } \\
\text { I can't drive my car at all. }\end{array}$ \\
\hline
\end{tabular}




\begin{tabular}{|c|c|}
\hline Sectiol & Section 10: Recreation: \\
\hline $\begin{array}{l}\square \text { I have no trouble sleeping. } \\
\square \text { My sleep is slightly disturbed (less than } 1 \text { hour } \\
\text { sleep loss). } \\
\square \text { My sleep is mildly disturbed (1-2 hour sleep loss.) } \\
\square \text { My sleep is moderately disturbed (2-3 hours sleep } \\
\text { loss). } \\
\square \text { My sleep is greatly disturbed (3-5 hours sleep loss). } \\
\square \text { My sleep is completely disturbed (5-7 hours sleep } \\
\text { loss). }\end{array}$ & $\begin{array}{l}\square \text { I am able to engage in all my recreational activities with no neck } \\
\text { pain at all. } \\
\square \text { I am able to engage in all my recreational activities with some } \\
\text { pain in my neck. } \\
\square \text { I am able to engage in most but not all of my usual recreational } \\
\text { activities because of pain in my neck. } \\
\square \text { I am able to engage in a few of my usual recreational activities } \\
\text { because of pain in my neck. } \\
\square \text { I can hardly do any recreational activities because of pain in my } \\
\text { neck. } \\
\square \text { I can't do any recreational activities at all. }\end{array}$ \\
\hline
\end{tabular}

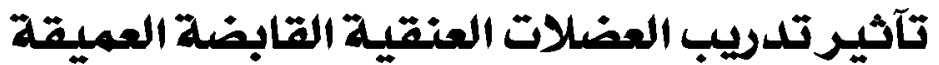

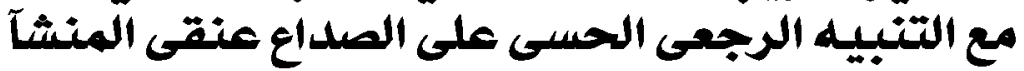

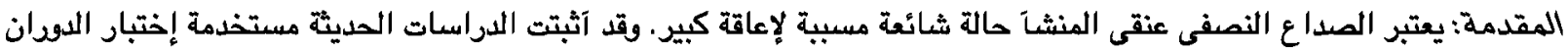

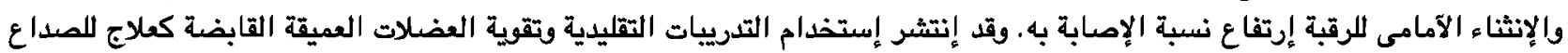
النصفى عنقى المنشاً.

الغرض: التحقق من وجود آيه فائدة إضـافية لتدريب العضلات العنقية القابضة العميقة مع التتبيه الرجعى الحسى عن التريبات التقليدية على مرضى الصداع عنقى المنشاً.

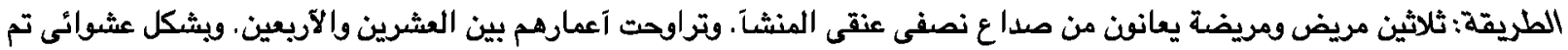

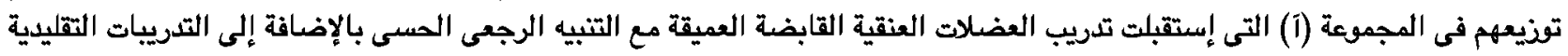

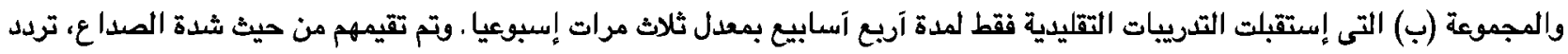
الصداع في الإسبوع، شدة آلم الرقبة، إعاقة الرقبة، ونطاق حركة الرقبة قبل وبعد البرناميج العلاجى.

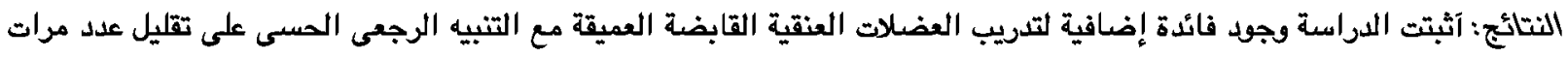
الصداع فى الإسبوع دون وجود فائدة إضافية على شدة الصداعة شدة الفرة آلم الرقبة، إعاقة الرقبة، ونطاق حركة الرقبة.

الإستستاجات: الصداع النصفى عنقى المنشاَ، آلم الرقبة المزمن، المنبه الجعى العسى، تدريب العضلات القابضة العميقة. 